\title{
Identifying the asthenospheric component of kimberlite magmas from the Dharwar Craton, India
}

\author{
Chad Paton $^{1}$, Janet M. Hergt ${ }^{1}$, David Phillips ${ }^{1}$, Jon D. Woodhead ${ }^{1}$ and Simon R. Shee ${ }^{2}$ \\ ${ }^{1}$ University of Melbourne, School of Earth Sciences, University of Melbourne, Parkville, Victoria 3010, Australia \\ ${ }^{2}$ Shee \& Associates Pty Limited, 74 Liston Street, Glen Iris, Victoria 3146, Australia
}

Geochemical studies of kimberlite magmas are hampered by the contamination of magmas with crustal and sub-continental lithospheric material (e.g. Le Roex et al., 2003). Although the inclusion of large amounts of such material is evident from the xenoliths and xenocrysts that are so common in kimberlite rocks (Mitchell, 1986; Patel et al, 2006), the degree of assimilation of the material and its effect on magma chemistry is less clear. A possible method of constraining the relative contributions of lithospheric and asthenospheric material to kimberlite magmas is to contrast intrusions emplaced in regions with differing cratonic roots. The Wajrakarur and Narayanpet kimberlite fields of southern India appear to be excellent subjects for such an approach. The fields are similar in age $(\sim 1100$ Ma vs. $\sim 1125 \mathrm{Ma}$; Paton, 2007; Kumar et al., 2007), and despite being only $\sim 300 \mathrm{~km}$ apart appear to be situated in regions of the Dharwar Craton with sub-continental lithospheric mantle (SCLM) of differing thickness, separated by a deepseated gravity anomaly (Haggerty and Birkett, 2004; Figure 1).

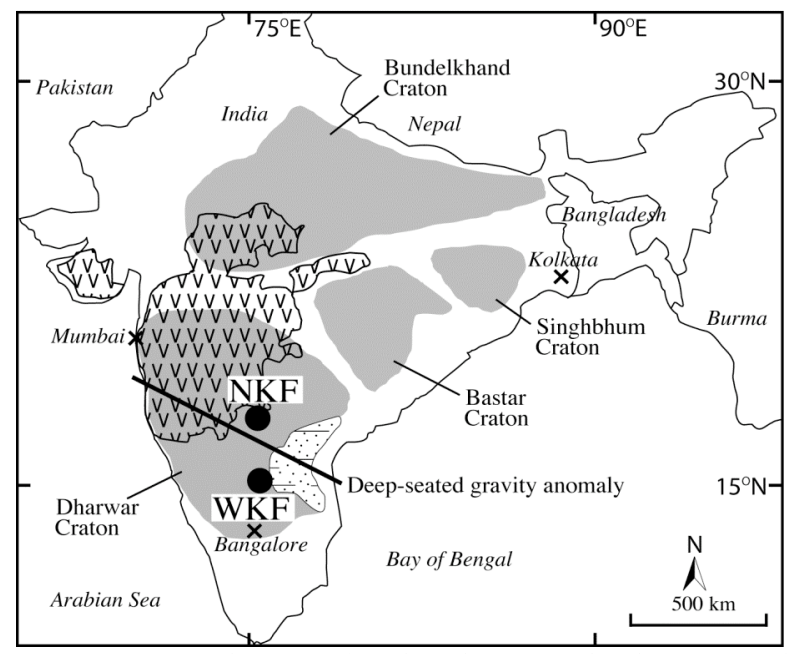

Fig. 1 Regional map of India showing the location of the Narayanpet Kimberlite Field (NKF) and Wajrakarur Kimberlite Field (WKF) within the Dharwar Craton and relevant geological features. Note the location of the deep-seated gravity anomaly (Haggerty and Birkett, 2004) between the two fields. After Paton et al. (2007).
We have conducted an in-depth geochemical study (major and trace elements and $\mathrm{Sr}-\mathrm{Nd}-\mathrm{Hf}$ isotopes) on 35 samples from 21 minimally altered intrusions of the Wajrakarur and Narayanpet kimberlite fields. In addition, we have analysed Sr-isotopes in perovskites from a subset of 11 of these intrusions (see Paton et al., 2007 for details of the method).

Because of the unusual nature of kimberlites, any interpretation of geochemical data must first consider the effects of alteration processes and crustal contamination on the samples. The effects of crustal contamination were assessed using a combination of the contamination index (Clement, 1982; with a cut-off value of 1.50 as suggested by Mitchell, 1986) and the $\mathrm{Gd} / \mathrm{Lu}$ ratios of samples (where low values are indicative of HREE enriched crustal contaminants, in this case with an arbitrary cut-off value of 58). Using these measures a total of seven samples were considered unacceptably contaminated by crustal material, and were removed from the dataset. Although the extremely high contents of $\mathrm{Hf}, \mathrm{Nd}$, and to a lesser extent $\mathrm{Sr}$, in kimberlites relative to crustal rocks are expected to buffer isotopic ratios of these elements against the effects of crustal contamination (Heaman, 1989), the isotopic results of those samples considered unacceptably contaminated by crustal material were nevertheless removed from the dataset.

The degree to which post-emplacement alteration has impacted major and trace element results can be assessed by comparing potentially affected elements to the fluid-immobile REE and HFSE (Le Roex et al., 2003). The latter exhibit strong internal consistency and are therefore unlikely to have been modified by alteration processes. The trace elements $\mathrm{Rb}, \mathrm{Sr}, \mathrm{Ba}$ and $\mathrm{K}$ appear strongly influenced by post-emplacement alteration processes, while $\mathrm{SiO}_{2}, \mathrm{MgO}, \mathrm{CaO}$ and $\mathrm{Al}_{2} \mathrm{O}_{3}$ also appear to have been affected to a lesser degree. Other elements, in particular the HFSE and REE appear undisturbed by these processes. Based on the above observations, bulk-rock $\mathrm{Hf}$ - and $\mathrm{Nd}$-isotope ratios are unlikely to have been affected by alteration, whereas bulk-rock Sr-isotope ratios are highly likely to have been disrupted. 
Despite the obvious effects of post-emplacement alteration on a number of major and trace elements, compositional variations within the more robust HFSE and REE suggest that the samples of this study strongly resemble those of southern African Group I kimberlites (Le Roex et al., 2003; Becker and Le Roex, 2006). Primitive mantle normalised multi-element plots (Figure 2a) exhibit extreme incompatible element enrichment, with maximum values at Th-U or Nb-La of 177 to 457 (c.f. 490 - 600 for Group I kimberlites), and slope steeply downwards toward the more compatible HREE. In addition, samples of this study exhibit negative anomalies of $\mathrm{Rb}, \mathrm{K}, \mathrm{Sr}, \mathrm{Pb}$ and $\mathrm{Ti}$ (relative to neighbouring elements on the plot), similar to southern African Group I kimberlites. Chondrite-normalised REE plots are also similar, with La abundances of 330 to 1070 times chondritic (c.f. Group I values of $365-$ 1420), dropping smoothly to the HREE, with Lu only 4.2 to 9.5 times chondritic (again similar to Group I at $2-8.6)$.
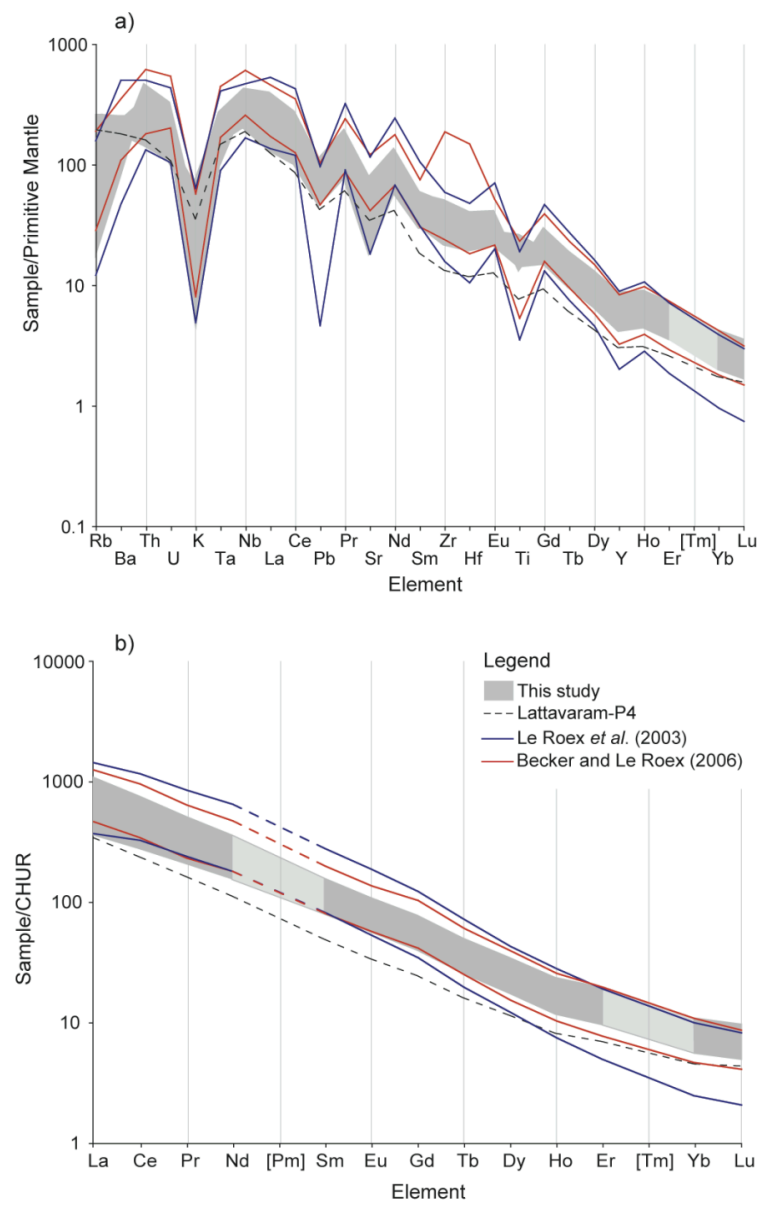

Fig. 2 (a) Primitive mantle normalised multi-element plots, and (b) Chondrite normalised REE plots comparing samples of this study (grey field) to the ranges of two separate datasets representing the Group I kimberlites of southern Africa. A single anomalous kimberlite of this study is indicated by a dotted line. Values for $\mathrm{Pm}$ and $\mathrm{Tm}$ were interpolated from neighbouring elements. The former does not occur naturally, and the latter was used as an internal standard. a)

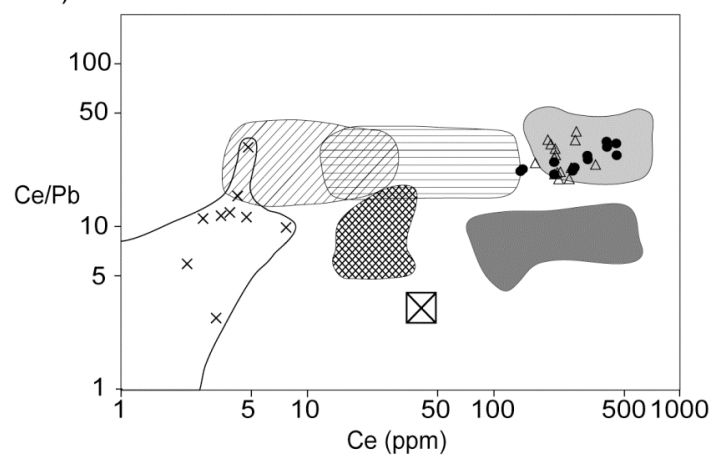

b)



Fig. 3 Log plots of (a) $\mathrm{Ce} / \mathrm{Pb}$ vs. Ce (ppm), and (b) $\mathrm{Nb} / \mathrm{U}$ vs. $\mathrm{Nb}$ (ppm), used to discriminate between mantle-derived rocks, which typically have uniform $\mathrm{Ce} / \mathrm{Pb}$ and $\mathrm{Nb} / \mathrm{U}$ ratios at $\sim 47$ and $\sim 35$ respectively (Hofmann et al., 1986), and continental rocks which have lower ratios in each case. Bulk-rock SCLM data are from Gregoire et al. (2003), whereas all other fields are after Le Roex et al. (2003).

Given the strong similarities of Indian kimberlites to those of southern Africa, it would be reasonable to conclude that similar processes were responsible for their formation. However, although the generally favoured model of Group I kimberlite genesis is via small-degree melting of metasomatised SCLM, there are several inconsistencies between this model and the geochemistry of the Narayanpet and Wajrakarur kimberlites. As noted above, it is expected that the SCLM of the two fields is likely to vary substantially in composition, yet incompatible element ratios are indistinguishable between the fields (Figure 3). In addition, when compared using plots of $\mathrm{Ce} / \mathrm{Pb}$ vs. Ce and $\mathrm{Nb} / \mathrm{U}$ vs. U (Figure 3), Indian kimberlites (and Group I kimberlites of southern Africa) are similar to OIB, but have no similarities to metasomatised garnet lherzolite of the SCLM (Gregoire et al. 2003). In contrast, southern African Group II kimberlites have lower $\mathrm{Ce} / \mathrm{Pb}$ and $\mathrm{Nb} / \mathrm{U}$ ratios (Le Roex et al., 2003), similar to the SCLM. 
Bulk-rock Nd and Hf isotope results for the two fields are also indistinguishable (Figure 4), with tightly clustered $\varepsilon \mathrm{Nd}_{\mathrm{i}}$ values of +1.2 to +3.1 and $\varepsilon \mathrm{Hf}_{\mathrm{i}}$ values of +0.8 to +5.0 (except for a single intrusion with $\varepsilon \mathrm{Hf}_{\mathrm{i}}$ of 3.0). These values fall completely within the range of southern African Group I kimberlites and are nearly identical to those in Greenland kimberlites. However, it is the Sr-isotope ratios obtained from groundmass perovskite that are striking, showing extreme homogeneity within each field, with $\mathrm{Sr}_{\mathrm{i}}$ ratios of $0.70233-0.70250$ and $0.70311-0.70332$ for the Wajrakarur and Narayanpet kimberlite fields respectively (black points, Figure 4; Paton et al., 2007). This contrasts with a spread in bulk-rock $\mathrm{Sr}_{i}$ ratios of $\sim 0.701$ to $\sim 0.709$ (white points, Figure 4).
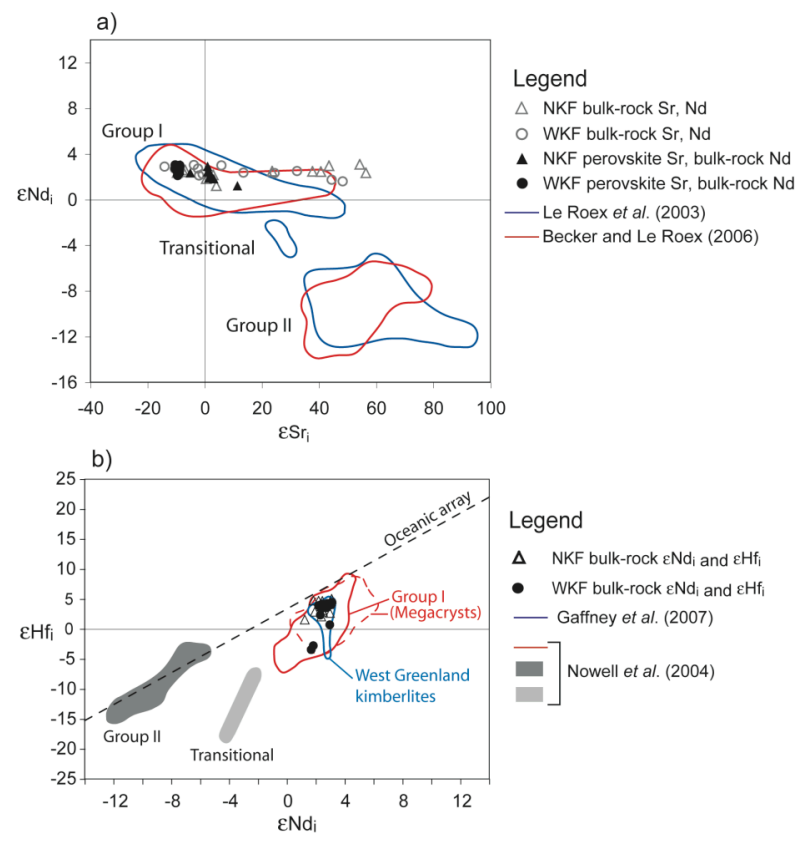

Fig. 4 Comparison of (a) $\varepsilon \mathrm{Nd}_{\mathrm{i}}$ vs. $\varepsilon \mathrm{Sr}_{\mathrm{i}}$ and (b) $\varepsilon \mathrm{Hf}_{\mathrm{i}}$ vs. $\varepsilon \mathrm{Nd}_{\mathrm{i}}$ for kimberlites of the Narayanpet and Wajrakarur kimberlite fields. Data from kimberlites of southern Africa (Le Roex et al., 2003; Becker and Le Roex, 2006) and west Greenland (Gaffney et al. 2007) are provided for comparison.

The homogeneity of Sr-isotope results further challenges models for the formation of kimberlite magmas by small-degree partial melting of the SCLM, which is thought to be highly heterogeneous. Instead, direct derivation from asthenospheric depths is favoured. If this is the case, the similarity in elemental and isotopic compositions of the Narayanpet and Wajrakarur kimberlite fields implies that the REE and HFSE were largely unaffected by assimilation of lithospheric material, and are a good reflection of the asthenospheric source component. In addition, the similarity of $\mathrm{Nd}$ and $\mathrm{Hf}$ isotopes in Indian kimberlites to Group I kimberlites in Greenland and southern Africa, despite a significant distribution in space and time, suggests that a common process within the asthenosphere may be responsible for kimberlite formation.

\section{References}

Becker, M. and Le Roex, A.P., 2006. Geochemistry of South African On-and Off- craton, Group I and Group II Kimberlites: Petrogenesis and Source Region Evolution. Journal of Petrology, 47 (4), 673703.

Clement, C.R., 1982. A Comparative Geological Study of Some Major Kimberlite Pipes in the Northern Cape and Orange Free State, PhD thesis, University of Cape Town.

Gaffney, A., Blichert-Toft, J., Nelson, B.K., Bizzarro, M., Rosing, M. and Albarede, F., 2007. Constraints on source-forming processes of West Greenland kimberlites inferred from Hf-Nd isotope systematics. Geochimica et Cosmochimica Acta, 71, 222-238.

Gregoire, M., Bell, D.R. and Le Roex, A.P., 2003. Garnet Lherzolites from the Kaapvaal Craton (South Africa): Trace Element Evidence for a Metasomatic History. Journal of Petrology, 44 (4), 629-657.

Haggerty, S.E. and Birkett, T., 2004. Geological setting and chemistry of kimberlite clan rocks in the Dharwar Craton, India. Lithos. 76 (1-4), 535-549.

Heaman, L.M., 1989. The nature of the subcontinental mantle from $\mathrm{Sr}-\mathrm{Nd}-\mathrm{Pb}$ isotopic studies on kimberlitic perovskite. Earth and Planetary Science Letters, 92 (3-4), 323- 334.

Hofmann, A.W., Jochum, K.P., Seufert, M. and White, W.M., 1986. $\mathrm{Nb}$ and $\mathrm{Pb}$ in oceanic basalts: new constraints on mantle evolution. Earth and Planetary Science Letters, 79 (1-2), 33-45.

Kumar, A., Heaman, L. and Mankyamba, C., 2007. Mesoproterozoic kimberlites in south India: A possible link to $\sim 1.1$ Ga global magmatism. Precambrian Research, 154 (3-4), 192-204.

Le Roex, A.P., Bell, D.R. and Davis, P., 2003. Petrogenesis of Group I Kimberlites from Kimberley, South Africa: Evidence from Bulk-rock Geochemistry. Journal of Petrology, 44 (12), 22612286.

Mitchell, R.H., 1986. Kimberlites: Mineralogy, Geochemistry, and Petrology. Plenum Press, New York, 442 pp.

Patel, S.C., Ravi, S., Thakur, S.S., Rao, T.K. and Subbarao, K.V., 2006. Eclogite xenoliths from Wajrakarur kimberlites, southern India. Mineralogy and Petrology, 88 (1), 363-380.

Paton, C., Hergt, J.M., Phillips, D., Woodhead, J.D. and Shee, S.R., 2007. New insights into the genesis of Indian kimberlites from the Dharwar Craton via in situ $\mathrm{Sr}$ isotope analysis of groundmass perovskite. Geology, 35 (11), 1011.

Paton, C., Woodhead, J.D., Hergt, J.M., Phillips, D. and Shee, S., 2007. Strontium Isotope Analysis of Kimberlitic Groundmass Perovskite via LA-MC-ICPMS. Geostandards and Geoanalytical Research, 31 (4), 321-330

Paton, C., 2007. The Petrogenesis of Indian Kimberlite Magmas: A geochemical and geochronological investigation into kimberlite intrusions from the Dharwar Craton, India. PhD thesis, University of Melbourne. 